\title{
Determinan Kebijakan Pemerintah Sebuah Solusi Keberlangsungan Usaha UMKM di Tengah Pandemi Covid-19
}

\author{
Hemas Citra Maharani*, Jaeni ${ }^{2}$ \\ Fakultas Ekonomi, Universitas Stikubank \\ *Email: hemascitra@gmail.com
}

\begin{abstract}
Penelitian ini bertujuan untuk menganalisis pengaruh pemberian bantuan sosial, insentif pajak, dan restrukturisasi kredit terhadap perkembangan UMKM di masa pandemi Covid19. Penelitian dilakukan pada UMKM Semarang Barat, Semarang Tengah, dan Semarang Selatan. Populasi dalam penelitian ini adalah pelaku UMKM yang telah memanfaatkan insentif pajak dan menerima bantuan sosial yang berada di Semarang Barat, Semarang Tengah 2, dan Semarang Selatan. Purposive sampling digunakan untuk mendapatkan sampel sebanyak 369 UMKM. Data penelitian diperoleh sebanyak 84 amatan secara mingguan sejak bulan April hingga Oktober tahun 2020 dengan menggunakan dengan metode dokumenter. Teknik analisis menggunakan regresi linier berganda untuk menguji hipotesis penelitian. Hasil penelitian menunjukkan bahwa pemberian bantuan sosial, insentif pajak, dan restrukturisasi kredit berpengaruh terhadap perkembangan UMKM di masa pandemi Covid-19. Hasil penelitian dapat memberikan informasi tambahan pemerintah dalam menyiapkan skema besar untuk program perlindungan dan pemulihan ekonomi bagi UMKM yang terdampak Covid-19 serta mengevaluasi strategi bisnis UMKM menuju model bisnis UMKM yang modern dengan tetap menjaga protokol kesehatan.
\end{abstract}

Kata kunci : Perkembangan UMKM, Bansos, Insentif Pajak, Restrukturisasi Kredit

\begin{abstract}
This study aims to analyze the effect of providing social assistance, tax incentives, and credit restructuring on the development of MSMEs during the Covid-19 pandemic. The research was conducted at UMKM West Semarang, Central Semarang and South Semarang. The population in this study were MSME actors who had taken advantage of tax incentives and received social assistance in West Semarang, Central Semarang 2, and South Semarang. Purposive sampling was used to obtain a sample of 369 MSMEs. The research data were obtained as many as 84 observations on a weekly basis from April to October 2020 using the documentary method. The analysis technique uses multiple linear regression to test the research hypothesis. The results showed that the provision of social assistance, tax incentives, and credit restructuring had an effect on the development of MSMEs during the Covid-19 pandemic. The results of the study can provide additional information for the government in preparing a large scheme for economic protection and recovery programs for MSMEs affected by Covid-19 as well as evaluating MSME business strategies towards modern MSME business models while maintaining health protocols.
\end{abstract}

Keywords: Development of MSMEs, Social Assistance, Tax Incentives, Credit Restructuring

\section{PENDAHULUAN}

Usaha Mikro Kecil dan Menengah (UMKM) menjadi salah satu pilar utama domestik perekonomian dalam negeri. UMKM merupakan bagian dari perekonomian nasional yang berwawasan kamandirian dan memiliki potensi besar untuk meningkatkan kesejahteraan masyarakat. Berbagai upaya dilakukan pemerintah untuk meningkatkan jumlah UMKM di daerah. Peran pemerintah sangat dibutuhkan untuk memberikan stimulasi kepada para pelaku usaha untuk meingkatkan perekonomian.

Melandanya masalah pandemi covid-19 hingga saat ini dialami semua sektor usaha termasuk UMKM. Permasalahan yang dihadapi UMKM seperti penurunan penjualan, permodalan, distribusi terhambat, kesulitan bahan baku, produksi menurun dan PHK buruh. Hal ini menjadi ancaman bagi perekonomian nasional. Karena UMKM sebagai penggerak ekonomi domestik dan penyerap tenaga kerja klas tengah menghadapi penurunan produktivitas yang berakibat pada penurunan profit secara signifikan. 
Teori daya tarik industri digunakan untuk menjelaskan dalam penelitian ini bahwa pemerintah melakukan usaha untuk mengembalikan kondisi dengan memberikan insentif dan subsidi (Lincoln, 2015). Bank Indonesia memperkirakan pada tahun 2020 pertumbuhan ekonomi dan laju inflasi sebesar 4,2-4,6 persen. Namun nyatanya angka pertumbuhan ekonomi dan laju inflasi tahun 2020 mengalami penurunan. Hal ini disebabkan karena kondisi force mayor yaitu dampak pandemi covid-19 yang sedang melanda hingga saat ini. Kondisi ini menjadikan salah satu sektor strategis dalam perekonomian nasional yaitu UMKM mengalami permasalahan dalam kegiatan usahanya dari sisi penawaran maupun permintaan. Menurut OEDC (2020) dan Febrantara (2020) dalam sisi penawaran UMKM menghadapi permasalahan tenaga kerja akibat dari pemberlakuan Pembatasan Sosial Berskala Besar (PSBB). Sedangkan pada sisi permintaan, yaitu berkurangnya permintaan barang dan jasa yang menyebabkan permasalahan likuiditas pelaku usaha sehingga sangat mengganggu kelangsungan usahanya.

Meningkatnya permasalahan yang dihadapi oleh pelaku UMKM khususnya dimasa pandemi covid-19 ini menjadi topik pembahasan yang menarik untuk diteliti lebih dalam untuk mengetahui penyebabnya dan bagaimana cara penanganannya. Terdapat empat permasalahan ekonomi yang dihadapi pelaku UMKM pada masa pandemi yaitu penurunan penjualan sebagai akibat aturan PSBB, kesulitan permodalan karena perputaran modal yang sulit, hambatan distribusi produk, dan kesulitan bahan baku. Melihat permasalahan yang mengglobal dihadapi hampir semua sektor UMKM maka menjadikan pemerintah mencari solusi permasalahan tersebut. Untuk memulihkan kondisi seperti semula maka perlu langkah mitigasi prioritas jangka pendek dengan memberikan stimulus pada sisi permintaan dan mendorong platform digital (online) untuk memperluas kemitraan. Upaya lainnya yaitu melalui kerjasama dalam pemanfaatan inovasi dan teknologi yang dapat menunjang perbaikan mutu dan daya saing produk, proses pengolahan produk, kemasan dan sistem pemasaran serta lainnya. Stimulus yang diberikan pemerintah seperti pemberian bantuan sosial kepada pelaku usaha; memberikan insentif pajak, melakukan relaksasi dan restrukturasi kredit; perluasan pembiayaan modal kerja; menempatkan kementerian BUMN, dan Pemerintah Daerah sebagai penyangga produk UMKM; dan pelatihan secara e-learning. Kebijakan yang dilakukan pemerintah ini sebagai bentuk implementasi teori model daya tarik industri yaitu adanya insentif dan subsidi dengan tujuan untuk mengembalikan posisi pasar.

Pemberian bantuan sosial yang dilakukan pemerintah sebagai salah satu bentuk penyelamatan UMKM pada masa pandemi Covid-19. Program penyaluran bantuan sosial tersebut dalam bentuk kemitraan UMKM, produksi jamu dan masker kain, pelonggaran kredit, dukungan bahan baku, distribusi paket sembako, dan penurunan tarif listrik. Sedangkan bentuk pemberian insentif pajak bagi UMKM diharapkan dapat menekan biaya operasional sehingga perekonomian dapat bertahan ditengah pandemi Covid-19. Pemberian retrukturisasi kredit dimaksudkan untuk memberikan kelonggaran waktu dalam penundaan pembayaran kewajiban kepada bank sesuai dengan POJK No 48/POJK.03/2020 tentang perubahan atas POJK No. 11/POJK.03/2020 tentang stimulus perekonomian nasional sebagai kebijakan Countercyclical dampak penyebaran Covid 19 dengan harapan dapat meringankan beban keuangan.

Hasil penelitian Sugiri (2020) menemukan bahwa pemberian bantuan sosial, insentif pajak berpengaruh positif terhadap perkembangan UMKM pada masa pandemi Covid-19. Penelitian Iping (2020) menemukan bahwa secara ekonomi pemberian bantuan sosial memberikan dampak yang signifikan terhadap kelangsungan usaha UMKM. Sedangkan hasil penelitian Bhagas (2016) menemukan bahwa bantuan pemerintah tidak berpengaruh terhadap pendapatan 52 UMKM Sulampita Kota Semarang. Berkaitan dengan insentif pajak, hasil penelitian Kumala et al. (2020) dan Selvi (2020) menemukan bahwa insentif pajak berpengaruh terhadap pelaku UMKM. Berbeda dengan Tandilino et al (2016) menemukan bahwa penerapan pajak terasa memberatkan UMKM di kota Kendari sehingga menurunkan penghasilan dan perkembangan UMKM. Hasil temuan diperkuat oleh Ra'ida et al (2019) bahwa adanya insentif pajak ternyata menjadikan UMKM belum secara sukarela membayar pajak karena merasa belum mendapatkan manfaat secara langsung, sehingga menjadikan rendahnya penerimaan pajak dari sektor UMKM. Penelitian restrukturisasi kredit berpengaruh signifikan negatif terhadap Non-Performing Loan (NPL) di Bank Mandiri Kanwil VI Bandung (Ridwan, 2018). Adanya retrukturisasi kredit sangat membantu pelaku usaha hasil laut dan pengusaha pancake durian di Makasar di tengah pandemic covid-19. 
Demikian juga restrukturisasi utang perusahaan go publik berpengaruh terhadap return saham (Yulazri, 2017). Sebelumnya oleh Hasibuan (2001) menunjukkan bahwa upaya restrukturisasi kredit sebagai langkah perbaikan yang dilakukan oleh Bank dalam kegiatan perkreditan terhadap debitur yang mengalami kesulitan untuk memenuhi kewajibannya. Penelitian tersebut dilakukan pada debitur kartu kredit dengan status penunggakan maksimal sebelum write off.

Adanya stimulus kebijakan pemerintah pada masa pandemic Covid-19, maka penelitian ini menggunakan pendekatan teori model daya tarik industri untuk menjelaskan perkembangan UMKM. Pendekatan teori ini dipandang lebih sesuai digunakan untuk menjelaskan perkembangan UMKM pada masa pandemi Covid 19. Hasil penelitian ini memberikan informasi tambahan bagi pemerintah dalam menyiapkan skema besar untuk program perlindungan dan pemulihan ekonomi bagi UMKM yang terdampak Covid-19 serta mengevaluasi strategi bisnis UMKM menuju model bisnis UMKM yang modern dengan tetap menjaga protokol kesehatan.

\section{Teori Model Daya Tarik}

Pembangunan ekonomi daerah adalah suatu prosedur yang dilakukan oleh pemerintah dan masyarakat dalam mengelola sumberdaya dengan membentuk mitra antara pemerintah daerah dengan sektor swasta yang dapat menciptakan lapangan kerja baru dan merangsang perkembangan ekonomi di wilayahnya (Lincoln, 2015). Pemerintah sebagai stimulator dalam pembangunan daerah dimana pemerintah daerah menciptakan stimulasi dan pengembangan usaha melalui tindakan khusus yang dapat mempengaruhi para pelaku usaha.

Penelitian ini menggunakan pendekatan teori model daya tarik sebagai salah satu teori pembangunan ekonomi daerah. Implementasi teori ini yaitu dengan dikeluarkannya PMK No.86 Tahun 2020 dan PMK No. 81/PMK.05/2012. Dalam teori ini pemerintah memberikan subsidi dan insentif bagi para pelaku usaha. Pemberian tersebut sebagai salah satu bentuk usaha untuk mempertahankan usaha para pelaku UMKM di masa pandemi Covid-19 yang telah memberikan dampak yang cukup signifikan penurunan pendapatan sehingga melemahkan pertumbuhan usaha pada suatu wilayah. Pemberian subsidi dan insentif bertujuan untuk mengembalikan posisi pasar Oleh karena itu teori ini sejalan dengan arah penelitian yang mengamati pemberian subsidi dan insentif untuk pelaku UMKM yang berupa pemberian bantuan sosial, insentif pajak, dan restrukturisasi kredit yang bertujuan untuk mengembangkan usaha pada masa pandemi Covid-19 khususnya di wilayah Semarang Barat, Semarang Tengah, dan Semarang Selatan.

\section{Usaha Mikro Kecil dan Menengah (UMKM)}

Usaha mikro, kecil, dan menengah merupakan suatu bentuk usaha perniagaan atau perdagangan yang pengelolaannya dilakukan oleh orang pribadi maupun badan usaha dan memiliki kriteria khusus dalam pengelompokan jenis usahanya. UMKM adalah bidang usaha yang terklasifikasi sebagai bentuk usaha dengan kekayaan bersih kurang dari 200 juta. Dasar kalkulasi penghitungan kekayaan tersebut disesuaikan dengan omzet atau laba penjualan dalam periode tahunan yang diterima oleh perusahaan (Kwartono, 201//).

Pengelompokan UMKM diatur oleh UU No.20 Tahun 2008 yaitu:

1. Usaha Mikro

Kriteria yang masuk UMKM adalah usaha mikro, yaitu suatu usaha atau perusahaan yang memiliki aset bersih usahanya kira-kira 50 juta perbulan. Biasanya untuk usaha jenis ini kekayaan yang berupa bangunan maupun perusahaan yang menjadi tempat usaha tidak masuk ke dalam kalkulasi. Selain itu usaha mikro memiliki ciri-ciri tertentu. Seperti belum pernah melakukan administrasi keuangan yang sistematis, sulit mendapat bantuan dari perbankan, barang yang dijual selalu berubah-ubah serta bentuk usahanya relatif kecil. Contoh seperti warung kelontong, peternak ayam, peternak lele, tukang cukur, dan warung nasi serta usaha yang sejenis.

2. Usaha Kecil

Usaha kecil juga merupakan kriteria badan usaha UMKM. Usaha kecil ini merupakan satu usaha yang dikelola oleh personal namun tidak tergolong sebagai badan usaha. Kekayaan usaha yang tergolong usaha kecil biasanya berada di bawah 300 juta per tahun. Ini merupakan kekayaan bersih yang sudah dikalkulasi secara sempurna. Ciri-ciri usaha kecil yaitu tidak memiliki sistem pembukuan, kesulitan untuk memperbesarkan skala usaha, usaha non ekspor 
impor serta masih memiliki modal yang terbatas. Jika dilihat dari perspektif ini tentu usaha kecil memiliki progres bisnis yang lebih tinggi dibandingkan usaha mikro. Contohnya seperti industri kecil, koperasi, minimarket, toserba, dan selainnya.

3. Usaha Menengah

Sebuah badan usaha bisa disebut usaha menengah apabila laba bersih atau kekayaan aset dari perusahaan mencapai 500 juta perbulan. Namun sama dengan kriteria usaha yang lain kekayaan seperti tanah dan bangunan sebagai tempat usaha di dalam jenis ini juga tidak dimasukkan ke dalam kalkulasi. Usaha menengah biasanya memiliki ciri-ciri manajemen usaha sudah lebih modern serta melakukan sistem administrasi keuangan sekalipun dengan model yang sangat terbatas. Tenaga kerja pada perusahaan dengan kriteria usaha menengah biasanya sudah mendapatkan jaminan kesehatan dan kerja. Sedangkan untuk perusahaannya sendiri maka minimal harus memiliki NPWP, izin tetangga dan legalitas yang lainnya. Contoh seperti usaha perkebunan, perdagangan ekspor impor, ekspedisi muatan kapal laut dan yang sejenis.

Dominasi UMKM di Indonesia perlu mendapat perhatian khusus karena kontribusi UMKM terhadap perekonomian nasional yang cukup besar (Pakpahan 2020). Namun perkembangan UMKM di Indonesia yang meningkat dari segi kuantitas tersebut belum diimbangi oleh meratanya peningkatan kualitas UMKM. Terdapat tiga peran UMKM sangat penting dalam kehidupan masyarakat kecil yakni sarana mengentaskan kemiskinan, meratakan tingkat perekonomian rakyat kecil, kontribusi devisa bagi Negara (Prasetyo et al, 2019).

\section{Perkembangan Usaha}

Perkembangan usaha merupakan suatu bentuk usaha yang dilakukan oleh pelaku usaha untuk meningkatkan usahanya (Fadilah, 2012). Suatu perkembangan dilakukan sebagai upaya pelaku bisnis untuk memperluas dan mempertahankan bisnis tersebut agar dapat berjalan dengan baik. Jika akan dilakukan pengembangan bisnis dibutuhkan dukungan dari berbagai aspek seperti bidang produksi dan pengolaan, pemasaran, SDM, teknologi, dan lain - lain.

UMKM secara keseluruhan mengalami perkembangan dan pertumbuhan yang baik seiring berganti tahun. Jumlah total unit UMKM dari tahun ke tahun mengalami kenaikan. Selanjutnya dalam pemberitaan terakhir, jumlah tersebut sudah mencapai angka 63 juta. Secara persentase, jumlah UMKM di Indonesia mencapai 99,9\% dari total unit usaha di Indonesia. Dengan data ini, dapat disimpulkan bahwa UMKM memiliki peran besar dalam menyumbang pertumbuhan ekonomi negara.

Perkembangan UMKM di Indonesia menunjukkan pola yang baik. Adanya dukungan dari pemerintah melalui cara-cara tertentu mempengaruhi angka pertumbuhan jumlah unit usaha mikro, kecil, dan menengah. Pemanfaatan sarana teknologi dan komunikasi, alokasi kredit usaha dari perbankan untuk rakyat, serta menurunnya tarif pajak PPh final menjadi beberapa faktor yang mendorong perkembangan UMKM di Indonesia. Namun demikian, pertumbuhan UMKM dinilai masih lambat karena beberapa faktor pendukung tersebut dinilai belum efektif. Salah satu kondisi ini adanya penurunan tarif $\mathrm{PPh}$ Final menjadi $0.5 \%$. Penurunan tarif dapat meningkatkan jumlah wajib pajak, namun dari Ditjen Pajak jumlah angka penerimaan masih kurang besar. Hal ini diyakini karena wajib pajak masih merasa kesulitan dalam memproses kewajiban perpajakannya.

\section{Bantuan Sosial}

Merujuk pada Permendagri No.39 Tahun 2012 Pasal 1 bahwa bantuan sosial merupakan pemberian bantuan berupa uang/barang dari pemerintah daerah kepada individu, keluarga, kelompok dan /atau masyarakat yang sifatnya tidak secara terus menurus dan selektif. Pemberian bantuan sosial tersebut bertujuan untuk mengurangi risiko sosial yang ditimbulkan dari kondisi tertentu. Dengan kata lain bantuan sosial merupakan suatu penyaluran dana yang dimiliki pemerintah yang diberikan kepada masyarakat dengan syarat tertentu. Adapun tujuan dari pemberian bantuan sosial tertuang dalam Peraturan Menteri Keuangan (PMK) Nomor 81/PMK.05/2012 yaitu sebagai rehabilitasi sosial, perlindungan sosial, pemberdayaan sosial, jaminan sosial, penanggulangan kemiskinan, dan penanggulangan bencana.

Masalah yang dihadapi dalam penyaluran bantuan sosial biasanya meliputi alokasi anggaran pada tiap kementrian berbeda,data yang penerima bantuan yang tidak terintegrasi,dan sistem 
penyaluran bantuan sosial tersebut (Rahmansyah et al, 2020). Untuk itu dibutuhkan kerjasama,koordinasi, dan harmonisasi antara pemerintah pusat, daerah, dan lembaga swasta agar tepat sasaran, efektif, dan efisien serta didukung oleh sistem yang baik,terintegrasi,transparan, dan akuntabilitas dalam penyaluran dana bantuan sosial tersebut. Kebijakan program bantuan sosial bagi UMKM yang terdampak Covid-19 di Kota Semarang memiliki beberapa bentuk bantuan yaitu, pemberian bahan baku produksi,bantuan langsung tunai, dan pembelian produk UMKM (Apriyanti 2020).

\section{Insentif Pajak}

Penerbitan Peraturan Menteri Keuangan (PMK) PMK-44/PMK.03/2020 oleh Menteri Keuangan tentang Insentif Pajak untuk Wajib Pajak Terdampak Pandemi Covid -19. Hal yang harus dipastikan terlebih dahulu oleh wajib pajak (WP) yang ingin memanfaatkan kebijakan ini adalah yang memiliki peredaran bruto tertentu dan dikenakan Pajak Penghasilan ( $\mathrm{PPh}$ ) final berdasarkan PP Nomor 23 Tahun 2018. PPh final UMKM ditanggung pemerintah (DJP) sebesar Rp2,4 triliun, serta pembiayaan investasi kepada koperasi melalui Lembaga Pengelola Dana Bergulir Koperasi,Usaha Mikro, Kecil, dan Menengah (LPDB KUMKM) sebesar Rp1 triliun Rupiah. (Kompas, 2 September 2020). Pelaku UMKM yang ingin memanfaatkan insentif ini tidak perlu mengajukan surat keterangan PP 23, tetapi cukup menyampaikan laporan realisasi setiap bulan.

Tarif $0,5 \%$ yang diatur oleh PP 23/2018 diperuntukkan bagi UMKM dengan peredaran bruto selama setahun tidak lebih dari Rp4,8 miliar. Subjeknya adalah orang pribadi, badan usaha berbentuk PT, CV, Firma, dan koperasi. Berdasarkan ketentuan tersebut, PPh final 0,5\% untuk pelaku UMKM ditanggung pemerintah (DJP) atau dibebaskan. Wajib pajak UMKM tidak perlu melakukan setoran pajak dan pemotong pajak tidak melakukan pemotongan pajak pada saat melakukan pembayaran kepada pelaku UMKM. Insentif ini diberikan untuk masa pajak April hingga September 2020. Bahkan pemerintah memperpanjang insentif pajak untuk membantu wajib pajak menghadapi dampak pandemi Covid-19 hingga 30 Juni 2021. Ketentuan ini terbit menggantikan PMK-86/PMK.03/2020 jo PMK-110/PMK.03/2020 yang mengatur tentang pemberian insentif pajak hingga 31 Desember 2020. Pengajuan permohonan insentif dapat dilakukan secara online melalui www.pajak. go.id. (kemenkeu.go.id, 22 Juni 2020).

\section{Restrukturisasi Kredit}

Restrukturisasi kredit adalah upaya perbaikan yang dilakukan dalam kegiatan perkreditan terhadap debitur yang berpotensi mengalami kesulitan untuk memenuhi kewajibannya. Restrukturisasi kredit/utang akan memberikan kelonggaran pada perusahaan untuk memenuhi kewajibannya, sehingga secara tidak langsung akan memberikan ruang bagi perusahaan untuk mengalokasikan dananya pada operasional perusahaan terlebih dahulu. Hal tersebut diharapkan akan berdampak secara tidak langsung pada kinerja keuangan perusahaan adanya perbedaan signifikan kinerja keuangan perusahaan pada periode sebelum dan setelah restrukturisasi utang dilakukan (Hotchkiss et al., 2008).

Kebijakan restrukturisasi kredit yang dilakukan pihak bank antara lain melalui: penurunan suku bunga kredit, perpanjangan jangka waktu kredit; pengurangan tunggakan bunga kredit; pengurangan tunggakan pokok kredit; penambahan fasilitas kredit; dan/atau konversi kredit menjadi penyertaan modal sementara. Restrukturisasi kredit UMKM dilakukan melalui penundaan pokok dan subsidi. Kebijakan ini berlandaskan hukum dari Peraturan Menteri Keuangan Nomor 65/PMK.05/2020 tentang Tata Cara Pemberian Subsidi Bunga/Subsidi Margin untuk Kredit/Pembiayaan Usaha Mikro, Kecil, dan Menengah dalam rangka mendukung pelaksanaan program pemulihan ekonomi nasional yang selanjutnya diperbaharui dengan Nomor 85/PMK.05/2020.

Kebijakan untuk UMKM dilakukan melalui penundaan angsuran pokok dan pemberian subsidi bunga untuk kredit usaha mikro dan kecil (kredit s/d. Rp500 juta) melalui BPR, perbankan, dan lembaga pembiayaan, maupun Kredit Usaha Rakyat (KUR) sebesar 6\% selama 3 bulan pertama dan 3\% selama 3 bulan kedua. Penundaan angsuran pokok dan pemberian subsidi bunga untuk kredit usaha menengahj juga diberikan pada usaha menengah (kredit Rp500 juta sampai Rp10 miliar) melalui BPR, perbankan, dan lembaga pembiayaan sebesar 3\% selama 3 bulan 
pertama dan 2\% selama 3 bulan kedua. Adapun kriteria UMKM yang dapat memperoleh subsidi bunga/margin, antara lain: (1) memiliki plafon kredit/pembiayaan paling tinggi Rp10.000.000.000; (2) memiliki sisa pokok (baki debet) kredit/pembiayaan sebelum masa pandemi Covid-19 (terdapat baki debet sampai dengan 29 Februari 2020); (3) tidak termasuk dalam Daftar Hitam Nasional; (4) memiliki kategori performing loan lancar (kolektibilitas 1 atau 2) dihitung per 29 Februari 2020; dan (5) memiliki NPWP atau mendaftar untuk mendapatkan NPWP

\section{Pengaruh Bantuan Sosial terhadap Perkembangan UMKM}

Bantuan sosial merupakan suatu bentuk bantuan yang diberikan oleh pemerintah secara berkala dan tidak terus menerus kepada individu, keluarga, kelompok dan atau masyarakan dalam bentuk uang maupun barang. Pemberian bantuan sosial tersebut bertujuan untuk mengurangi risiko sosial yang ditimbulkan dari kondisi tertentu .

Pemberian bansos seperti tertuang pada peraturan pemerintah mengenai pengembangan UMKM yang dilakukan seperti dalam Undang-Undang No.20 Tahun 2008 Pasal 16, bahwa bantuan ini sebagai wujud kepedulian pemerintah terhadap masyarakat. Adanya kebijakan bantuan sosial yang diberikan pemerintah pusat untuk menyokong sektor informal dan pekerja harian, serta memberi stimulus bagi usaha kecil, mikro dan menengah. Bantuan sosial dalam bentuk bantuan langsung tunai (BLT) merupakan salah satu bagian dari paket stimulus lanjutan yang kini sedang dipersiapkan oleh pemerintah. Bantuan ini akan ditujukan langsung pada pekerja sektor informal termasuk UMKM antara lain pekerja warung, toko kecil, pedagang di pasar, hingga pekerja harian lainnya termasuk di pusat-pusat perbelanjaan.

Adanya bantuan pemerintah ini diharapkan agar pelaku usaha tetap dapat mempertahankan kemampuan usaha ekonomi, meningkatkan produktivitas kerja, meningkatkan penghasilan, dan menjaga kemitraan usaha yang saling menguntungkan terlebih lagi di tengah pandemi. Semakin merata pemberian bansos yang diterima pelaku UMKM, diharapkan dapat membantu mempertahankan usaha dan meningkatkan penghasilan dengan tetap menjaga protokol kesehatan. Penelitian Iping (2020) dan Sugiri (2020) menemukan bahwa bantuan sosial berpengaruh terhadap perkembangan UMKM. Berdasarkan pengembangan teoritis dan penelitian terdahulu maka dapat dirumuskan hipotesis sebagai berikut :

$H_{1}$ : Bantuan sosial berpengaruh positif terhadap perkembangan UMKM di masa pandemi Covid-19.

\section{Pengaruh Insentif Pajak terhadap Peerkembangan UMKM}

Pemerintah menggunakan pajak untuk pembangunan nasional dan kemakmuran seluruh warga negara. Akan tetapi pemerintah melakukan kebijakan dalam memberikan insentif pajak kepada UMKM dengan tujuan untuk memulihkan perekonomian negara. Adanya insentif pajak tersebut diharapkan dapat membantu para pelaku UMKM dalam menghadapi perekonomian di masa pandemi sebagai bentuk pengurangan beban. Adanya kebijakan insentif pajak diharapkan mendorong UMKM agar tetap berperan serta dalam kegiatan ekonomi formal dan memberikan kemudahan dan meringankan pelaku UMKM sebagai bentuk keadilan kepada wajib pajak.

Banyaknya pelaku UMKM yang memanfaatkan insentif pajak diharapkan dapat membantu mempertahankan usaha UMKM agar tetap berjalan sehingga dapat mempertahankan pendapatan di tengah kondisi pandemi. Penelitian Selvi (2020); Sugiri (2020); dan Kumala, Ratih dan Junaidi (2020) menemukan insentif pajak memiliki pengaruh positif terhadap pendapatan usaha UMKM. Berdasarkan pengembangan teoritis dan penelitian terdahulu maka dapat dirumuskan hipotesis sebagai berikut:

$\mathrm{H}_{2}$ : Insentif pajak berpengaruh positif terhadap perkembangan UMKM di masa pandemi Covid-19.

\section{Pengaruh Restrukturisasi Kredit terhadap Perkembangan UMKM}

Kebijakan pemerintah (OJK) memberikan stimulus melalui restrukturisasi kredit dalam bentuk keringanan bunga bank atau subsidi bunga bank. Kebijakan ini merupakan upaya memberikan keringanan bagi debitur perbankan khususnya UMKM untuk tetap dapat menghidupkan usahanya yang terdampak Covid-19. Hal ini terlihat pada UMKM di Sulawesi 
Selatan di bidang ekspor, pengusaha pancake durian, yang mengalami penurunan omset terbukti yang berhasil mempertahankan usahanya di masa Covid-19 (Makasar, Antara, 2020). Adanya kredit KUR dari lembaga perbankan seperti BNI, Mandiri, BRI, BTN, Maybank, BCA, Bukopin, dan BRIS dirasakan oleh beberapa pengusaha atau UMKM sangat terbantu adanya program keringanan pembiayaan tanpa pembayaran pinjaman pokok atau penundaan angsuran. Pengawasan dana KUR selalu terus dilakukan pemerintah dan tentunya tetap dilakukan monitoring setiap bulan dan kunjungan setiap tiga bulan untuk memantau kondisi usaha debitur.

Restrukturisasi perbankan tersebut berdampak luas, bukan hanya pada kondisi keuangan, tetapi juga pada kondisi ekonomi yang menggantungkan hidup melalui kucuran modal. Termasuk beberapa orang yang dipekerjakan, akibatnya terjadi pengurangan tenaga kerja. Adapun keringanan subsidi bunga atau restrukturisasi kredit selama pandemi sebesar 6 persen pada 3 bulan pertama dan 3 persen di tiga bulan berikutnya. Untuk itu pemerintah pusat melalui Kementerian Koperasi dan Usaha Kecil Menengah (UKM) menyiapkan dana Pemulihan Ekonomi Nasional (PEN) bagi pelaku UMKM se Indonesia, dengan harapan dapat mempertahankan UMKM di masa pandemi.

Berdasarkan pengembangan teoritis dan penelitian terdahulu maka dapat dirumuskan hipotesis sebagai berikut:

\section{$\mathrm{H}_{3}$ : Restrukturisasi kredit berpengaruh positif terhadap perkembangan UMKM di masa pandemi Covid-19.}

\section{METODE PENELITIAN}

Jenis penelitian yang digunakan adalah metode penelitian eksplanatori dengan kuantitatif yaitu pendekatan untuk menjelaskan hubungan bantuan sosial, insentif pajak, dan restrukturisasi kredit atas perkembangan UMKM di masa Covid-19. Analisis statistika deskriptif dalam penelitian ini digunakan untuk menjelaskan dan menyimpulkan variabel penelitian dengan pengukuran sentral tendensi. Analisis sentral tendensi dalam penelitian ini untuk menginterpretasikan nilai minimum, maksimum, mean, median, dan standar deviasi.

\section{Jenis dan Sumber Data}

Data yang digunakan dalam penelitian ini adalah kuantitatif. Sedangkan menurut sumber data yang digunakan sebagai referensi adalah data sekunder yaitu data keuangan yang diperoleh secara mingguan sejak bulan April hingga bulan Oktober tahun 2020. Adapun sumber data diperoleh dari Dinas Koperasi dan UMKM kota Semarang berupa data perubahan jumlah UMKM dan data bantuan sosial. Selanjutnya dari KPP Semarang Barat, KPP Semarang Tengah 2, dan KPP Semarang Selatan berupa data realisasi insentif pajak. Sedangkan dari PT Pegadaian (Persero) berupa data retrukturisasi kredit dalam bentuk penundaan angsuran.

\section{Populasi dan Sampel Penelitian}

Populasi dalam penelitian ini adalah pelaku UMKM yang berada diwilayah Semarang Barat, Semarang Tengah 2, dan Semarang Selatan yang tercatat pada Dinas Koperasi dan UMKM Kota Semarang sejumlah 698. Sedangkan sampel penelitian terpilih secara purposive sampling adalah pelaku UMKM secara kontinyu yang telah (1) mendaftarkan diri sebagai penerima BANPRES dan bentuk bantuan lainnya, (2) UMKM yang telah memanfaatkan insentif pajak, dan (3) UMKM yang mendapatkan penundaan angsuran melalui PT. Pegadaian (Persero). Berdasarkan kriteria tersebut maka diperoleh sampel sebanyak 369 UMKM.

\section{Metode Pengumpulan Data}

Pengumpulan data yang dilakukan melalui dokumentasi, mengelola data, artikel, jurnal maupun media tertulis lainnya yang berkaitan dengan topik pembahasan digunakan peneliti dalam mendapatkan infomasi yang relevan. Studi dokumentasi adalah metode pengumpulan data dengan mengumpulkan data sekunder yang berkaitan dengan penelitian sehingga dapat menyelesaikan permasalahan dalam penelitian ini, seperti pelaku UMKM yang menjadi sampel penelitian. Data tersebut diperoleh dari Dinas UMKM Kota Semarang, KPP wilayah Semarang Barat, Semarang Tengah 2, KPP Semarang Selatan, dan PT. Pegadaian (Persero) Semarang. 


\section{Definisi Operasional dan Pengukuran variabel Pemberian Bantuan Sosial}

Bantuan sosial merupakan wujud program ketahanan ekonomi bagi rumah tangga miskin dalam menghadapi guncangan yang diperhatikan dari sisi pangan,pendidikan,kesehatan maupun krisis ekonomi serta bencana alam (Palupi,et al,2019). Dasar peraturan pemberian bantuan sosial untuk UMKM yaitu Peraturan Menteri Koperasi, Usaha Kecil, dan Menengah Republik Indonesia Nomor 6 Tahun 2020. Indikator yang digunakan untuk mengukur bantuan sosial seperti yang digunakan oleh Arifin (2020) yaitu pemberian paket sembako, masker non medis, minuman herbal, dan sabun cuci tangan. Pengukuran variable bansos menggunakan skala rasio.

\section{Insentif Pajak}

Insentif pajak (tax incentive) merupakan bentuk penawaran dari pemerintah melalui pemanfaatan pajak dalam kegiatan tertentu, seperti kontribusi uang atau harta untuk kegiatan yang berkualitas (Gitiyarko, Vincentus dan Chryshna 2020). Dasar peraturan insentif pajak untuk UMKM yaitu PMK Nomor 86/PMK.03/2020 dan PMK Nomor 110/PMK.03/2020. Indikator yang digunakan untuk mengukur insentif pajak seperti yang digunakan oleh Kumala, Ratih dan Junaidi (2020) yaitu jumlah beban pajak yang ditanggung pemerintah. Pengukuran variable insentif pajak menggunakan skala rasio.

\section{Restrukturisasi Kredit}

Restrukturisasi Kredit adalah upaya perbaikan yang dilakukan dalam kegiatan perkreditan terhadap debitur yang mengalami kesulitan untuk memenuhi kewajibannya. Restrukturisasi yang dilakukan antara lain melalui: penurunan suku bunga, penundaan angsuran, potongan waktu kredit, penghapusan bunga hutang, maupun penambahanan fasilitas kredit. Dasar kebijakan restrukturisasi kredit merujuk pada kebijakan pemerintah (Otoritas Jasa Keuangan/OJK) yaitu Peraturan Menteri Keuangan Nomor 65/PMK.05/2020 tentang Tata Cara Pemberian Subsidi Bunga/Subsidi Margin untuk Kredit/Pembiayaan Usaha Mikro, Kecil, dan Menengah. Indikator yang digunakan untuk mengukur restrukturisasi kredit menggunakan jumlah UMKM yang menerima penundaan angsuran pada salah satu lembaga keuangan perbankan di kota Semarang. Pengukuran variable restrukturisasi kredit menggunakan skala rasio.

\section{Perkembangan Usaha Mikro Kecil dan Menengah (UMKM)}

Perkembangan UMKM adalah perubahan bertambahnya jumlah UMKM dari tahun ke tahun yang mengarah peningkatan. Perkembangan ini termasuk bertambahnya kemampuan (skill) menjadi lebih baik agar mencapai pada satu titik atau puncak menuju kesuksesan. Perkembangan usaha di lakukan oleh usaha yang sudah mulai terproses dan terlihat ada kemungkinan untuk lebih maju lagi. UMKM adalah suatu bentuk usaha yang dimiliki oleh perorangan atau badan usaha dan memiliki kriteria dalam pengelompokan jenis usahanya (Sugiri 2020). Perkembangan peran usaha UMKM yang besar ditunjukkan oleh jumlah unit usaha dan pengusaha, serta kontribusinya terhadap pendapatan nasional, dan penyediaan lapangan kerja. Dasar peraturan mengenai UMKM yaitu Undang-Undang No.20 Tahun 2008. Dalam undang-undang tersebut pada bagian Bab VI Pasal 20 terdapat peraturan mengenai pemerintah dan pemerintah daerah memfasilitasi pengembangan usaha dengan memberikan insentif bagi UMKM guna mengembangankan teknologi dan keberlangsungan usaha. Indikator yang digunakan untuk mengukur UMKM seperti yang digunakan oleh Sugiri (2020) yaitu jumlah UMKM yang tercatat pada Dinas Koperasi dan UMKM Semarang Barat, Semarang Tengah 2, dan Semarang Selatan. Adapun pengukuran variable UMKM menggunakan skala rasio.

\section{Teknik Analisis Data}

Penelitian ini melakukan analisis data menggunakan regresi linier berganda dalam menguji hipotesis perkembangan UMKM di masa pandemi Covid-19. Sebelum melakukan regresi data dilakukan dilakukan pengujian dengan statistik deskriptif. Selanjutnya dilakukan uji asumsi klasik untuk memenuhi BLUE (Best Linier Unbiased Estimator) pada model regresi yang terdiri dari (1) uji normalitas, (2) uji multikolinieritas, (3) uji heteroskedastisitas, dan (4) uji Autokorelasi. 
Analisis regresi linier berganda memiliki pemanfaatan dalam pengukuran hubungan antara dua variabel atau lebih dalam penelitian, serta menunjukkan arah hubungan antara variabel independen dengan variabel dependen (Ghozali, 2018). Adapun persamaan regresi dalam penelitian ini sebagai berikut.

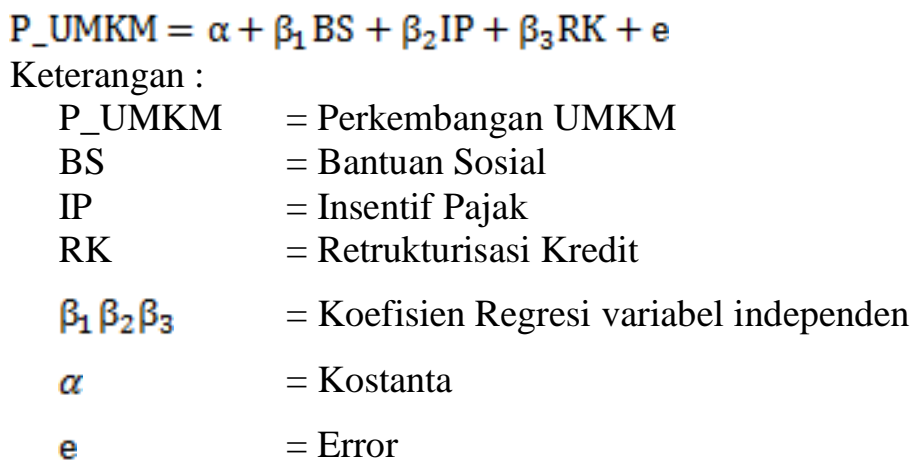

HASIL DAN PEMBAHASAN

Analisis statistik deskriptif pada penelitian ini dapat memberikan gambaran mengenai central tendency pada setiap variable. Hasil analisis statistik deskriptif terlihat pada tabel 1 berikut.

\begin{tabular}{lr|r|r|r|r} 
& \multicolumn{2}{c}{ Tabel 1. Statistik Deskriptif } \\
& $\mathrm{N}$ & Minimum & Maximum & \multicolumn{1}{c}{ Mean } & Std. Deviation \\
\hline $\begin{array}{l}\text { Perkembangan_UM } \\
\text { KM }\end{array}$ & 84 & 30.00 & 332.00 & 117.3214 & 83.59255 \\
\hline Bansos & 84 & 335161.00 & 41666666667. & 4065955219.98 & 9386420815.20 \\
& & 00 & 81 & 252 \\
\hline Insentif_Pajak & 84 & 14468943.0 & 294550767.00 & 76849992.2143 & 69143942.5618 \\
\hline $\begin{array}{l}\text { Restrukturisasi_Kred } \\
\text { it }\end{array}$ & 84 & 28.00 & 302.00 & 105.7976 & 72.54791 \\
\hline Valid N (listwise) & 84 & & & & \\
\hline
\end{tabular}

Sumber: Data sekunder diolah, 2021

Tabel 1 menunjukkan jumlah data berjumlah 84 amatan yang berasal dari UMKM Semaramg Barat, Semarang Tengah 2, dan Semarang Selatan. Nilai minimum sebesar 30 nilai maksimum 332, dari bulan April hingga bulan Oktober secara mingguan tahun 2020 diketahui nilai mean sebesar 117,3214 sedangkan standar deviasi sebesar 83.59255. Hasil tersebut menunjukkan nilai mean lebih besar dari standar deviasi sehingga penyimpangan data yang terjadi rendah maka penyebaran nilainya merata.

Variable bantuan sosial memiliki nilai minimum sebesar 335.161, nilai maksimal sebesar 41,666.666.667, dari bulan April hingga bulan Oktober secara mingguan tahun 2020 diketahui nilai mean sebesar 4065955219.9881 dan standar deviasi sebesar 9386420815.20252. Hasil tersebut menunjukkan nilai mean lebih kecil dari nilai standar deviasi sehingga penyimpangan data yang terjadi lebih tinggi maka penyebaran nilainya tidak merata.

Variabel insentif pajak memiliki nilai minimum sebesar 14.468.943, nilai maksimum sebesar 294.550.767, dari bulan April hingga bulan Oktober secara mingguan tahun 2020 diketahui nilai mean sebesar 76849992.2143 dan standar deviasi sebesar 69143942.56181. Hasil tersebut menunjukkan nilai mean lebih besar dari nilai standar deviasi sehingga penyimpangan data yang terjadi rendah maka penyebaran nilainya merata.

Variabel retrukturisasi kredit memiliki nilai minimum sebesar 28 nilai maksimimum sebesar 302, dan dari bulan April hingga bulan Oktober secara mingguan tahun 2020 diketahui nilai mean 105.7976 dan standar deviasi sebesar 72.54791. Hasil tersebut menunjukkan nilai mean lebih besar dari nilai standar deviasi sehingga penyimpangan data yang terjadi rendah maka penyebaran nilainya merata. 


\section{Uji Normalitas}

Uji normalitas model regresi nampak pada gambar 1 menunjukkan penyebaran data berada disekitar garis diagonal dan mengikuti arah diagonalnya, maka dapat disimpulkan data memiliki distribusi normal.

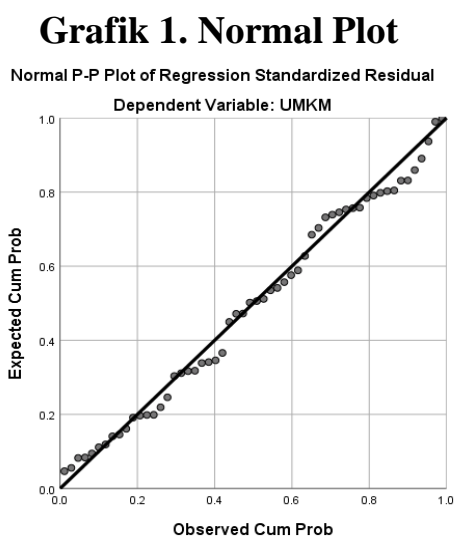

Sumber : Data sekunder diolah, 2021

\section{Uji Multikolinieritas}

Uji multikolinieritas dilakukan dengan melihat nilai variance inflation factor test (VIF) seperti pada tabel 2 berikut.

\begin{tabular}{|c|c|c|}
\hline \multirow[b]{2}{*}{ Model } & \multicolumn{2}{|c|}{$\begin{array}{l}\text { Collinearity } \\
\text { Statistics }\end{array}$} \\
\hline & $\begin{array}{c}\text { Toleranc } \\
\mathrm{e}\end{array}$ & VIF \\
\hline \multicolumn{3}{|l|}{ (Constant) } \\
\hline Bansos & .864 & 1.158 \\
\hline Insentif Pajak & .898 & 1.183 \\
\hline $\begin{array}{l}\text { Restrukturisasi_Kr } \\
\text { edit }\end{array}$ & .897 & 1.164 \\
\hline
\end{tabular}

Sumber : Data sekunder diolah, 2021

Nilai VIF $<10$ maka dapat disimpulkan bahwa semua data pada variable penelitian yang digunakan tidak terjadi multikolinieritas.

\section{Uji Heteroskedastisitas}

Uji heteroskedastisitas pada penelitian ini menggunakan Glejser test pada tabel 3 berikut.

Tabel 3. Uji Heterokedastisitas

\begin{tabular}{|l|r}
\multicolumn{1}{|c|}{ Model } & \multicolumn{1}{c}{ Sig. } \\
\hline (Constant) & .284 \\
\hline Bansos & .692 \\
\hline Insentif_Pajak & .080 \\
\hline Restrukturisasi_Kredit & .073 \\
\hline Dependent Variable: absres & \\
Sumber : Data sekunder diolah, 2021
\end{tabular}

Nilai hasil uji heteroskedastisitas menunjukkan signifikansi > 0,05, maka disimpulkan semua data pada variabel penelitian yang digunakan tidak terjadi heterokedastisitas. 


\section{Uji Kesesuaian Model}

Uji kesesuaian model regresi dalam penelitian ini terlihat dari koefisien determinasi dan uji F. Koefisien determinasi digunakan untuk mengukur seberapa jauh kemampuan suatu model dalam menjelaskan variance dependen. Hasil pengujian koefisien determinasi terlihat pada tabel 4 berikut.

Tabel 4. Uji Koefisien Determinasi $\left(\mathbf{R}^{2}\right)$

\begin{tabular}{ll|r|r|r|r} 
Model & $\mathrm{R}$ & $\mathrm{R}$ Square & $\begin{array}{c}\text { Adjusted R } \\
\text { Square }\end{array}$ & $\begin{array}{c}\text { Std. Error of } \\
\text { the Estimate }\end{array}$ & $\begin{array}{c}\text { Durbin- } \\
\text { Watson }\end{array}$ \\
\hline 1 & $.990^{\mathrm{a}}$ & .981 & .980 & 11.88432 & 1.953 \\
\hline
\end{tabular}

a. Predictors: (Constant), Restrukturisasi_Kredit, Bansos, Insentif_Pajak

b. Dependent Variable: Perkembangan_UMKM

Sumber : Data sekunder diolah, 2021

Tabel 4 menunjukkan nilai adjusted $\mathrm{R}$ square sebesar 98,0\%. Nilai ini menunjukkan sebesar 98,0 \% model penelitian ini mampu menjelaskan varian perkembangan UMKM artinya model ini mempunyai kemampuan menjelaskan lebih baik, sehingga model dikatakan fit.

\section{Uji Hipotesis}

Pengujian hipotesis terlihat pada tabel 5 berikut.

\begin{tabular}{|c|c|c|c|c|c|c|}
\hline \multirow[b]{3}{*}{ Model } & \multicolumn{6}{|c|}{ Tabel 5. Uji Hipotesis } \\
\hline & & \multicolumn{2}{|c|}{$\begin{array}{l}\text { Unstandardized } \\
\text { Coefficients }\end{array}$} & \multirow{2}{*}{$\begin{array}{c}\text { Standardized } \\
\text { Coefficients } \\
\text { Beta }\end{array}$} & \multirow[b]{2}{*}{$\mathrm{t}$} & \multirow[b]{2}{*}{ Sig. } \\
\hline & & $\mathrm{B}$ & Std. Error & & & \\
\hline \multirow[t]{4}{*}{1} & (Constant) & 1.680 & 2.570 & & .654 & .515 \\
\hline & Bansos & 4.573E-11 & .000 & .005 & 2.306 & .041 \\
\hline & Insentif_Pajak & $2.562 E-7$ & .000 & .212 & 4.256 & .000 \\
\hline & $\begin{array}{l}\text { Restrukturisasi_Kr } \\
\text { edit }\end{array}$ & .909 & .058 & .789 & $\begin{array}{r}15.77 \\
5\end{array}$ & .000 \\
\hline
\end{tabular}

a. Dependent Variable: Perkembangan_UMKM

Sumber : Data sekunder diolah, 2021

Berdasarkan tabel 5 menunjukkan bahwa $\mathrm{H}_{1}, \mathrm{H}_{2}$ dan $\mathrm{H}_{3}$ terbukti diterima. Artinya pemberian bantuan sosial, insentif pajak, dan restrukturisasi kredit berpengaruh positif terhadap perkembangan UMKM pada masa pandemi Covid-19. Merujuk pada tabel 5 dapat dirumuskan persamaan matematis sebagai berikut:

$$
\text { P_UMKM }=1.680+4.573 \mathrm{E}-11 \mathrm{BS}+2.562 \mathrm{E}-7 \mathrm{IP}+909 \mathrm{RS}
$$

\section{Pemberian Bantuan Sosial terhadap Perkembangan UMKM di Masa Pandemi Covid-19}

Hasil uji hipotesis menunjukan bahwa bantuan sosial berpengaruh positif terhadap perkembangan UMKM pada masa pandemi Covid-19. Temuan ini membuktikan bahwa program bantuan sosial dapat diterima merata oleh pelaku UMKM di wilayah Semarang Barat, Semarang Tengah 2, dan Semarang Selatan. Jumlah UMKM yang menerima bantuan dari bulan April hingga bulan Oktober mengalami peningkatan. Hal ini menunjukkan jumlah UMKM yang mengalami kesulitan ekonomi cukup banyak dan jumlah ini mengalami peningkatan. Adanya bantuan sosial dari pemerintah dalam bentuk pemberian bahan produksi UMKM, masker, minuman herbal, sabun, dan Bantuan Langsung Tunai (BLT) atau Bantuan Presiden (BANPRES) diberikan secara berkala dapat membantu menyelamatkan usaha yang kurang stabil akibat pandemi Covid-19. Temuan ini mendukung teori daya tarik industri bahwa adanya Peraturan Menteri Keuangan (PMK) No.81/PMK.05/2012 sebagai jaring perlindungan sosial dan membantu menanggulangi kondisi insidental karena Covid 19 pada pelaku UMKM dapat membantu usaha tetap bertahan dengan tetap menjaga protokol kesehatan. Hal ini dipandang UMKM sebagai pilar mampu membantu pemerintah dalam memulihkan kondisi perekonomian. Untuk itu perlu fasilitas protokol kesehatan dan fasilitas penunjang usaha lainnya melalui bantuan sosial tersebut. Temuan ini sejalan dengan 
penelitian Sugiri (2020) bahwa bantuan sosial berhasil menyelamatkan dari dampak pandemi Covid-19 dan juga relevan dengan penelitian Iping (2020) bahwa bantuan sosial mempertahankan daya beli serta kelompok pelaku usaha untuk kelangsungan usaha sehingga dapat meningkatkan pengembangan usaha di masa pandemi Covid-19.

\section{Insentif Pajak terhadap Perkembangan UMKM di Masa Pandemi Covid-19}

Hasil uji hipotesis kedua menunjukkan bahwa insentif pajak berpengaruh positif terhadap perkembangan UMKM pada masa pandemi Covid-19. Hasil penelitian ini menunjukkan bahwa pelaku UMKM di wilayah Semarang Barat, Semarang Tengah 2, dan Semarang Selatan telah memanfaatkan insentif pajak, meskipun di awal bulan April belum semua UMKM memanfatkan fasilitas tersebut. Namun selanjutnya jumlah tersebut mengalami peningkatan sampai dengan bulan Oktober. Wajib pajak UMKM yang menerima insentif perlu memenuhi persyaratan seperti peredaran bruto tertentu dan dikenai PPh final berdasarkan PP Nomor 23 Tahun 2018, surat keterangan berdasarkan PMK-44/PMK.03/2020, dan menyampaikan laporan realisasi PPh final ditanggung pemerintah paling lambat tanggal 20 setelah berakhirnya masa pajak (Pajak 2020). Persyaratan tersebut perlu disosialisasikan oleh pemerintah agar lebih banyak pelaku UMKM yang dapat memanfaatkan insentif pajak tersebut sehingga dapat membantu menjaga kelangsungan usahanya dimasa pandemi Covid-19.

Momen tersebut direspon baik oleh pelaku UMKM karena sangat membantu menurunkan beban pengeluaran. Temuan ini mendukung teori daya tarik industri bahwa insentif pajak sebagai salah satu wujud bentuk implikasi dari teori tersebut. Implementasi teori tersebut didukung munculnya PMK No.86 Tahun 2020 yang mengatur insentif pajak untuk wajib pajak terdampak pandemic Covid-19 bahwa dipandang perlu melakukan penanganan dengan melakukan perluasan sektor yang akan diberikan insentif perpajakan yang diperlukan selama masa pemulihan ekonomi nasional dengan memberikan kemudahan pemanfaatan insentif yang lebih luas. Pemerintah beranggapan karena Covid-19 merupakan bencana nasional yang mempengaruhi stabilitas ekonomi dan produktivitas masyarakat sebagai pekerja maupun pelaku usaha sehingga perlu upaya pengaturan pemberian insentif pajak untuk mengurangi dampak tersebut. Temuan ini sejalan dengan penelitian Kumala et al. (2020) bahwa pelaku UMKM sangat mengapresiasi dan terbantu dalam menurunkan beban operasional di masa pandemi Covid-19. Selvi dan Ramdhan (2020) menunjukkan insentif pajak sebagai penstabil keadaan yang berdampak pada keuangan pelaku usaha dapat mempengaruhi perkembangan UMKM di masa pandemi.

\section{Restrukturisasi Kredit terhadap Perkembangan UMKM di Masa Pandemi Covid-19}

Hasil uji hipotesis ketiga menunjukkan bahwa retrukturisasi kredit berpengaruh positif terhadap perkembangan UMKM pada masa pandemi Covid-19. Hasil penelitian ini menunjukkan bahwa jumlah pelaku UMKM di wilayah Semarang Barat, Semarang Tengah 2, dan Semarang Selatan yang melakukan restrukturisasi kredit meningkat melalui subsidi bunga bank termasuk penundaan angsuran. Kondisi ini direspon baik oleh pelaku UMKM terbukti jumlah debitur perbankan khususnya UMKM meningkat dalam mengajukan keringanan angsuran. Hal ini dilakukan agar tetap dapat menghidupkan usahanya yang terdampak Covid-19. Adanya kebijakan pemerintah melalui OJK tersebut dapat menurunkan risiko usaha melalui perpanjangan waktu pembayaran dan pemberian subsidi bunga pinjaman.

Adanya restrukturisasi kredit menjadikan usaha tetap dapat berjalan sehingga jumlah tenaga kerja yang dipekerjakan tidak mengalami pengurangan. Hal ini juga didukung jumlah UMKM cukup banyak yang menerima subsidi bunga 6 persen pada 3 bulan pertama sejak Covid 19 dan dilanjutkan subsidi bunga 3 persen pada 3 bulan berikutnya. Adanya keringanan tersebut menjadikan pelaku UMKM tidak begitu terbebani dengan pembayaran angsuran rutin disaat omzet turun drastis di masa pandemic.

Temuan ini mendukung teori daya tarik industri bahwa restrukturisasi kredit dalam bentuk subsidi bunga sebagai salah satu wujud bentuk implikasi dari teori tersebut. Secara hukum, subsidi bunga UMKM tercantum dalam PMK Nomor 65/PMK.05/2020 tentang Tata Cara Pemberian Subsidi Bunga/Subsidi Margin untuk Kredit/Pembiayaan Usaha Mikro, Kecil, dan Menengah dalam Rangka Mendukung Pelaksanaan Program Pemulihan Ekonomi Nasional. Subsidi Bunga 
UMKM tidak hanya diberikan kepada pelaku UMKM yang memiliki utang usaha di bank umum saja, namun juga bank syariah dalam bentuk subsidi margin. Temuan ini mendukung penelitian Yulazsri (2017) dan Rastogi \& Mazumdar (2016) bahwa periode satu minggu setelah restrukturisasi utang menjadikan abnormal return lebih tinggi

\section{KESIMPULAN DAN SARAN}

Berdasarkan hasil pengujian statistik dan pembahasan maka dapat disimpulkan bahwa:

1. Pemberian bantuan sosial berpengaruh terhadap perkembangan UMKM di masa pandemi Covid-19, artinya semakin besar bansos maka semakin cepat perkembangan UMKM

2. Insentif pajak berpengaruh terhadap perkembangan UMKM di masa pandemi Covid-1, artinya semakin besar insentif pajak maka semakin cepat perkembangan UMKM.

3. Restrukturisasi kredit terbukti berpengaruh terhadap perkembangan UMKM di masa pandemi Covid-19, artinya semakin besar subsidi bunga dari pemerintah maka akan menjadikan UMKM semakin cepat terpulihkan

4. Model penelitian mampu menjelaskan variance perkembangan UMKM di masa pandemi Covid-19 sebesar 98,0\%, artinya perkembangan UMKM dapat dijelaskan lebih baik pada melalui model ini.

Peneliti selanjutnya perlu memperluas wilayah penelitian. Hal ini dimaksudkan agar data yang dihasilkan lebih mewakili dan dapat digeneralisasi untuk wilayah Semarang secara keseluruhan. Peneliti selanjutnya perlu melihat restrukturisasi kredit dalam satuan nilai nominal dari lembaga keuangan yang lain seperti bank Jateng, bank BRI, bank Mandiri, bank BNI, dan lembaga keuangan lainnya. Hal ini dilakukan dengan harapan agar dapat dilakukan studi komparasi antar penbankan dan lembaga keuangan.

\section{DAFTAR PUSTAKA}

Apriyanti, Hani Werdi \& Syofii Muhammad. 2020. Pattrio Semarang Kebijakan Pengadaan Sosial Program Bantuan UMKM Terkena Pandemi di Kota Semarang. Semarang.

Arifin, Danung. 2020. Jaring Pengaman Sosial Kurangi Dampak Ekonomi Masyarakat di Tengah Pandemi COVID-19.

Bhagas, Arva. 2016. Analisis Pengaruh Modal, Jumlah Tenaga Kerja, Teknologi Dan Bantuan Pemerintah Terhadap Pendapatan Usaha Mikro Kecil Dan Menengah (Studi Kasus UMKM Sulampita Di Kota Semarang). Skripsi. Fakultas Ekonomi Universitas Diponegor.

Fadilah, Harris. 2012. Pengembangan Usaha. (https://harrisfadilah.wordpress.com/2012/04/ diakses 25 Desember 2020).

Febrantara, D. 2020. Bagaimana Penanganan UKM Di Berbagai Negara Saat Ada Pandemi Covid19. DDT Fiscal Research.

Ghozali, Imam. 2020. 25 Grand Theory. Semarang: Yoga Pratama.

Gitiyarko, Vincentus dan Chryshna, Mahatma. 2020. Kebijakan Perlindungan Dan Pemulihan UMKM Di Tengah Pandemi Covid-19.

Gonibala, Nirfandi., et al. 2019. Analisis Pengaruh Modal Dan Biaya Produksi Terhadap Pendapatan Umkm Di Kota Kotamobagu. Jurnal Berkala Ilmiah Efisiensi Vol 19 No.1 Hlm. 56-67.

Hotchkiss, E. S., John, K., Mooradian, R. M., \& Thorburn, K. S. (2008). Bankruptcy and The Resolution of Financial Distress. Handbook of Empirical Corporate Finance, 2(6). https://doi.org/10.1016/S1873-1503(06)01003-8

Hutahaean, Haposan. 2020. Analisis Faktor Faktor Yang Mempengaruhi Pendapatan Usaha Kecilmenengah (Ukm) Masa Pandemi Covid19 Di Kabupaten Deliserdang. Journal Economic and Strategy (JES) Vol 1 No.1 Hlm.1-10.

Iping, Baso. 2020. Perlindungan Sosial Melalui Kebijakan Program Bantuan Langsung Tunai (Blt) Di Era Pandemi Covid-19: Tinjauan Perspektif Ekonomi Dan Sosial. Jurnal Manajemen Pendidikan Dan Ilmu Sosial Vol 1 No. 2 Hlm.516-26.

Kasmir. 2016. Pengantar Manajemen Keuangan. Jakarta: Kencana Prenada Media Group.

Keuangan, Kementrian. 2020. Pembiayaan Ultra Mikro (UMi). (https://www.kemenkeu.go.id/umi diakses 13 januari 2021).

Khairiyah Ra'ida, Yotasa dan Akhmadi Heru, Muhammad. 2019. Studi Kualitatif: Dampak 
Kebijakan Insentif Pajak Usaha Kecil Dan Menengah Terhadap Kepatuhan Pajak Dan Penerimaan Negara. Jurnal Manajemen Keuangan Publik (MKP) Vol 3 No. 2 Hlm: 36-45.

Kumala, Ratih dan Junaidi, Ahmad. 2020. Strategi Bisnis Dan Pemanfaatan Kebijakan Pajak Di Masa Pandemi COVID-19 Dan Era New Normal (Studi Kasus Pelaku UKM Marketplace). Prosiding Seminar STIAMI Vol 7 No. 2 Hlm.98-103.

Lincoln, Arsyad. 2015. STIE YKPN. Yogyakarta Ekonomi Pembangunan, Edisi Kelima. ed. Badan Penerbitan Sekolah Tinggi Ilmu Ekonomi YKPN. Yogyakarta.

OEDC. 2020. Tackling Coronavirus (COVID-19) Contributing to a Global Effort. SME Policy Respons.

Pajak, Direktorat Jendral. 2020. DJP Insentif Pajak Untuk Wajib Pajak Terdampak Pandemi COVID-19.

Pakpahan, Kristian Aknolt. 2020. COVID-19 Dan Implikasi Bagi Usaha Mikro, Kecil, Dan Menengah . Jurnal Ilmiah Hubungan Internasional. Edisi Khusus Hlm 59-64.

Polandos Monika, Prisilia., et al. 2019. Analisis Pengaruh Modal, Lama Usaha, Dan Jumlah Tenaga Kerja Terhadap Pendapatan Usaha Mikro Kecil Dan Menengah Di Kecamatan Langowan Timur. Jurnal Berkala Ilmiah Efisiensi Vol 19 No.4 Hlm.36-47.

Prasetyo, Anton dan Huda, Miftahul. 2019. Analisis Peranan Usaha Kecil Dan Menengah Terhadap Penyerahan Tenaga Kera Di Kabupaten Kebumen. Fokus Bisnis: Media Pengkajian Manajemen dan Akuntansi Vol 18 No.1 Hlm. 26-35.

Rahmansyah, Wildan., et al. 2020. Pemetaan Permasalahan Penyaluran Bantuan Sosial Untuk Penanganan COVID-19 Di Indonesia. Jurnal Pajak dan Keuangan Negara Vol 2 No.1 Hlm. 90-102.

Rastogi, A., \& Mazumdar, S. (2016). Corporate Debt Restructuring (CDR) and its Impact on Firms ' Stock Market Performance: A Study of Pre- and PostCDR Shareperice Movements. South Asian Journal of Management, 23(3), 7-26.

Ridwan. Mohammad. 2018. Analisis Pengaruh Restrukturisasi Kredit, Recovery Rate, Baki Debet (BADE) dan Write Off (WO) Terhadap Non-Performing Loan (NPL) Pada Unit Card Collection PT. Bank Mandiri Kanwil VI Bandung. Jurnal Bisnis. Hlm.1-23. http://repository.stp-bandung.ac.id//handle/123456789/668

Saragih, I dan Nasution, S. 2015. Analisis Pengaruh Modal Sendiri Dan Modal Pinjaman Kredit Usaha Rakyat (KUR) Terhadap Pendapatan UMKM. Jurnal Akuntansi dan Pajak Vol 19 No.1 Hlm 1-7.

Selvi, Ramdhan Alief. 2020. Kajian Kebijakan Pemberian Insentif Pajak Dalam Mengatasi Dampak Virus Corona Di Indonesia Tahun 2019. Transparansi: Jurnal Ilmiah Ilmu Administrasi Vol 3 No.1 Hlm.96-100.

Sugiri, Dani. 2020. Menyelamatkan Usaha Mikro, Kecil, Dan Menengah Dari Dampak Pandemi Covid-19. Fokus Bisnis: Media Pengkajian Manajemen dan Akuntansi 19.

Tandilino, Albertus., et al. 2016. Penerapan Pajak Dalam Meningkatkan Penerimaan Pajak Penghasilan Final Sektor UMKM Di Kota Kendari. Jurnal Progres Ekonomi Pembangunan Vol 1 No.1 Hlm.1-14.

Winardi. 2011. Kamus Ekonomi. Bandung: Mandar Maju.

Yulazri.2017. Analisis Pengaruh Restrukturisasi Hutang Terhadap Return Saham Pada Perusahaan Go Publik Di Bursa Efek Jakarta Yang Melakukan Restrukturisasi Pada Tahun 2003. Jurnal Ekonomi Vol. 8 No. 2 Hlm. 116-134. 